\title{
Effect of Plane of Nutrition on Growth of Crossbred Calves
}

\author{
Narendra Kumar*, Ramjee Gupta, P. K. Upadhyay, Satendra Kumar and Deepak Singh \\ Department of Animal Husbandry and Dairying, C.S.A. Unit of Agriculture and Tech. \\ Kanpur, India \\ *Corresponding author
}

\section{A B S T R A C T}

\section{Keywords}

Wheat straw,

Concentrate

mixture, Crossbred calves

\section{Article Info}

Accepted:

10 October 2020

Available Online:

10 November 2020
The present experiment conducted at dairy farm during year 2016-17 at C.S.A. University of agricultural and technology Kanpur. The growth rate of crossbred female calves is major problem at dairy farm. Twelve crossbred female calves were selected for digestibility that on nutrition Slid samples contains $86.5 \%$ DM. $20.1 \%$ CP, $2 \%$ EE, $15.5 \%$ $\mathrm{CF}, 52.7 \% \mathrm{NFE}$, and $9.5 \%$ ash. The average DM intake per $100 \mathrm{~kg}$ body weight was (4.01, 4.04 , and $4.04 \mathrm{~kg}$ ) the digestibility coefficient of DM were Recorded $(60.21,60.71,60.48)$ and digestibility coefficient of CP $(64.34,64.35,62.34)$ and digestibility coefficient of EE $(60.83,60.65,61.59)$ and digestibility coefficient of CF. (57.67, 57.58, 56.27) and digestibility coefficient of NEE $(64.46,61.44,63.12$,). The average live Weight, Length, and heart girth, in crossbred female calves were increased (176.40, 186.65, and 215.40) gm per day. (1.25, 1.32 and 1.48) cm per week (0.83, 0.94, And 1.14) cm per week in T1, $\mathrm{T} 2$, and T3 group respectively, the parameters growth witch studied were statistically non significant. The group T3, was shown better performance in respect of Growth parameters in other groups $\mathrm{T} 1$ and $\mathrm{T} 2$ from the present study, it was apparent that the extra concentrate to be added in died for proper development of growing calves T3 group were higher in growth than T1 and T2 groups. Digestibility coefficient of DM, CF, and NFE, were also higher in group $\mathrm{T} 3$.

\section{Introduction}

Livestock sector plays a crucial role in shaping the rural economy of India. It is a major continuous income generating activity for the rural households. Livestock rearing and crop husbandry are the two important components of mixed farming which influence agricultural economy leading to sustainable agriculture and are complementary to each other. On an average animal husbandry contributes about 27 per cent to agricultural gross domestic product (GDP) of the country, whereas, the contribution is much higher in hot semi-arid and arid region where conventional crop production is always a gamble due to uncertain and scanty rainfall. Livestock \& fisheries sector contribute over 4.11 per cent of total GDP of India (Economic Survey 2017-18). A symbiotic relationship exists between men, land and livestock. India is endowed with largest livestock population in the world. Schloss et al., (1911) defines 
growth as a, "Correlated increase in Mass of the body in definite intervals of time in a way characteristic of species. The true growth involves an increase in the structural tissue such as muscle and bone of organs. It should be distinguished from the increase that results from fat deposition in the reserve tissues. Thus, growth is characterized by an increase in protein, mineral matter and water from the nutritional sage point it involves in addition a large intake of energy producing nutrients to support the growth process and an adequate nutrients to support the growth.

\section{Materials and Methods}

\section{Selection of calves}

The Twelve calves have been selected approximately similar age of within two year and similar weight from herd these calves divided in to three groups each Consisting of four calves each group thus constituted had four calves the calves. The calves allotted to each group were strictly in random distribution on the basis of similarity in age and conditions for weight similarly in age. Conditions for weight similarly happened to be practically impossible, so variation within the weight was controlled through replication for eliminating much the response made. The Following table 1 represents the schedule of controlling the weight variation through replications for eliminating much the response to groups made the Variations trough replications.

\section{Method of feeding}

Out of three groups one group was fed according to Morrison's (1948) standard of feeding while the animal of other two groups were kept respectively at a concentrate mixture intake of $20 \%$ above the Morrison's standard (T1) and $20 \%$ below the Morrison's standard (T1) Attempt was made to keep the intake equal to Monition's recommended average values for different body in all the groups. The concentrates were supplied in the morning of each day. The experiment was continued for 8 weeks all the precautions regarding feeding and sanitation were taken into consideration.

\section{Digestibility trial}

Two digestibility trial of 7 days duration each were conducted to determine the digestibility coefficient of dry matter, crude protein, ether extract, crude fiber, nitrogen free extract and organic matter of wheat straw and Berseem. The feces residues were discarded two days before the actual collection period during this period. Feces was collected separately and carefully weighed after twenty four hours. Each sample was taken then mixed thoroughly and small amount was taken as random from the different portion of the bulk in a wide mouthed glass tapered bottle and taken to the laboratory suitable aliquant was weighed for analysis.

\section{Results and Discussion}

The chemical composition of green berseem, wheat straw and concentrate mixture are presented table 1 . The variation in chemical composition of concentrate mixture in different proportion of deliberately was due to meet the nutritional requirement of the buffalo calves on the two dietary régimes. The DM, CP, CF, EE, and NFE, berseem was reported by Rajagopal and Murty (1983).

\section{Plan of nutrition}

The twelve buffalo female calves were taken and divided into three equal groups $\left(\mathrm{T}_{1}, \mathrm{~T}_{2}\right.$, and $\mathrm{T}_{3}$ ) having four animals in each group. In group $T_{2}$, the animal were fed conventional feeding system in $T_{3}$ and $T_{1}$ were fed more than $20 \%$ and less than $20 \%$ recommended 
dose of concentrate respectively. Wheat straw was offered ad-lib and $4 \mathrm{~kg}$ berseem offered to each animal.

\section{Nutrient intake}

The dry matter consumption per day recorded was recorded from $4.86 \pm 0.10,4.77 \pm 0.10$ and $4.65 \pm 0.068 \mathrm{~kg}$. There was significant difference in dry matter consumption per day among the groups. Similar observation were recorded by Mishra et al., (1994).The dry matter consumption per $100 \mathrm{~kg}$ body weight was observed $4.01 \pm 0.38,4.04 \pm 0.50$, and $4.04 \pm 0.36$. There was non significant difference among the groups. The dry matter intake when estimated on the basis of metabolic body size, it varied from 100.41 \pm
9.73, $102.54 \pm 11.92$, and $101.24 \pm 9.07 \mathrm{~g}$ per day. Statistically non significant difference was found in dry matter consumption per 100 $\mathrm{kg}$ metabolic body size between the various groups of animals. Similar observation was recorded by Fluharty and Loerch (1994). The intake of DCP was varied from $368.02 \pm 2.27$, $400.90 \pm 11.14$ and $473.73 \pm 1.80 \mathrm{~g} /$ day and TDN were varied from $2.51 \pm 0.02,2.87 \pm$ 0.06 , and $2.90 \pm 0.09 \mathrm{~kg} /$ day. The higher consumption of DCP and TDN in group III, than the group I, the higher consumption of DCP and TDN due to the presence of concentrate mixture in ration. There was significant difference in DCP and TDN among all the groups. Similar results were also reported by Chauhan et al., (2000) (Table 2 and 3 ).

Table.1 Schedule of control of the weight variations through replications

\begin{tabular}{|l|c|c|c|c|}
\hline S. No. & Ear no. & $\begin{array}{c}\text { Initial body wt. } \\
(\mathbf{k g})\end{array}$ & Date of birth & $\begin{array}{c}\text { Allotment of } \\
\text { treatments }\end{array}$ \\
\hline $\mathbf{1}$ & & 125 & $08 / 08 / 2016$ & $\mathrm{~T} 1$ \\
$\mathbf{2}$ & 29 & 140 & $08 / 08 / 2016$ & $\mathrm{~T} 2$ \\
$\mathbf{3}$ & 30 & 120 & $20 / 08 / 2016$ & $\mathrm{~T} 3$ \\
$\mathbf{4}$ & 31 & 153 & $20 / 08 / 2016$ & $\mathrm{~T} 1$ \\
\hline $\mathbf{5}$ & 35 & 115 & $08 / 10 / 2016$ & $\mathrm{~T} 2$ \\
$\mathbf{6}$ & 36 & 157 & $08 / 10 / 2016$ & $\mathrm{~T} 3$ \\
$\mathbf{7}$ & 38 & 125 & $25 / 07 / 2015$ & $\mathrm{~T} 1$ \\
$\mathbf{8}$ & 42 & 147 & $31 / 08 / 2016$ & $\mathrm{~T} 2$ \\
\hline $\mathbf{9}$ & 46 & 129 & $06 / 09 / 2016$ & $\mathrm{~T} 3$ \\
$\mathbf{1 0}$ & 47 & 132 & $27 / 09 / 2016$ & $\mathrm{~T} 1$ \\
$\mathbf{1 1}$ & 48 & 125 & $01 / 11 / 2016$ & $\mathrm{~T} 2$ \\
$\mathbf{1 2}$ & 50 & 156 & $08 / 11 / 2016$ & $\mathrm{~T} 3$ \\
\hline
\end{tabular}

Table.2 Chemical composition of ration fed to different groups

\begin{tabular}{|l|c|c|c|c|c|c|}
\hline Feed materials & $\begin{array}{c}\text { DM } \\
(\boldsymbol{\%})\end{array}$ & $\begin{array}{c}\text { CP } \\
(\boldsymbol{\%})\end{array}$ & $\begin{array}{c}\text { EE } \\
(\boldsymbol{\%})\end{array}$ & $\begin{array}{c}\text { CF } \\
(\boldsymbol{\%})\end{array}$ & $\begin{array}{c}\text { NFE } \\
(\boldsymbol{\%})\end{array}$ & $\begin{array}{c}\text { Total Ash } \\
(\boldsymbol{\%})\end{array}$ \\
\hline Wheat straw & 90.00 & 3.00 & 1.00 & 38.00 & 46.00 & 12.00 \\
\hline Berseem & 20.00 & 16.50 & 2.50 & 24.50 & 46.25 & 10.25 \\
\hline Concentrate & 90.00 & 20.00 & 1.80 & 15.60 & 51.10 & 11.50 \\
\hline
\end{tabular}


Table.3 Showing the average value at different proximate principal and Weight gain (gm) per days

\begin{tabular}{|c|c|c|c|}
\hline Sr. no. particular & $\mathbf{T}_{1}$ & $\mathbf{T}_{2}$ & $\mathbf{T}_{3}$ \\
\hline 1. Dry matter intake $(\mathrm{kg})$ & $4.86 \pm 0.10$ & $4.77 \pm 0.10$ & $4.65 \pm 0.068$ \\
\hline Metabolic body size (gm) & $100.41 \pm 9.73$ & $102.54 \pm 11.92$ & $101.24 \pm 9.07$ \\
\hline $\begin{array}{l}\text { Dry matter intake/ } 100 / \mathrm{kg} \text { ) } \\
\text { Metabolic body wt. }\end{array}$ & $4.01 \pm 0.38$ & $4.04 \pm 0.50$ & $4.04 \pm 0.36$ \\
\hline DCP intake (gm) & $368.02 \pm 2.27$ & $400.90 \pm 11.14$ & $473.73 \pm 1.80$ \\
\hline TDN intake (kg) & $2.51 \pm 0.02$ & $2.87 \pm 0.06$ & $2.90 \pm 0.09$ \\
\hline \multicolumn{4}{|l|}{ Nutrients digestibility } \\
\hline Dry matter (\%) & $60.21 \pm 1.31$ & $61.39 \pm 1.39$ & $62.70 \pm 2.00$ \\
\hline Crude fiber $(\%)$ & $60.21 \pm 1.31$ & $62.71 \pm 2.00$ & $63.48 \pm 1.39$ \\
\hline Crude protein $(\%)$ & $62.34 \pm 1.22$ & $63.35 \pm 2.51$ & $64.34 \pm 1.41$ \\
\hline Ether extract $(\%)$ & $60.83 \pm 0.38$ & $61.65 \pm 1.21$ & $62.59 \pm 0.72$ \\
\hline Nitrogen free extract $(\%)$ & $61.44 \pm 0.79$ & $63.12 \pm 1.68$ & $64.46 \pm 0.72$ \\
\hline 6. Organic matter $(\%)$ & $61.29 \pm 1.50$ & $62.97 \pm 1.27$ & $63.56 \pm 1.13$ \\
\hline 7. Weight gain (gm) per day & $138.49 \pm 3.46$ & $139.80 \pm 3.55$ & $140.76 \pm 3.63$ \\
\hline 8. Length gain $(\mathrm{cm})$ per day & $125.75 \pm 2.96$ & $128.53 \pm 2.92$ & $129.72 \pm 3.70$ \\
\hline 9. Heart girth gain $(\mathrm{cm})$ per day & $150.45 \pm 2.92$ & $151.24+2.59$ & $152.01+2.31$ \\
\hline
\end{tabular}

\section{Digestibility of nutrients}

The digestibility coefficient of dry matter in I, II and III groups were 60.21 \pm 1.31 , $61.39 \pm 1.39, \quad 62.70 \pm 2.00$ per cent, respectively. The data on dry matter digestibility were statistically significant. The higher digestibility of dry matter was observed in III, group. Increased dry matter digestibility suggests that most protein in basal protein supplement becoming available to ruminal microbes did rapidly after consumption similar observation were also reported by Barajas et al., (2014) in murrah buffalo calves. The average digestibility of crude protein $62.34 \pm 1.22,63.35 \pm 2.51$, $64.34 \pm 1.41$ percent in I, II, and III, group, respectively. These data are statistically significant. The present study indicated that an increase in concentrate mixture in diets, results in increased digestibility of crude protein. The view of present finding was supported by work of Madhuri and Suman
(2008). The average digestibility of ether extract $60.83 \pm 0.38,61.65 \pm 1.21,62.59 \pm 0.72$ percent in I, II and III group respectively. These data are statistically significant. Similar observation was also recorded by Singh et al., (2008).

The average digestibility of crude fiber $60.21 \pm 1.31,62.71 \pm 2.00,63.48 \pm 1.39$ percent in I, II and III group respectively. These data are statistically significant. The higher digestibility of crude fiber groups III compared group I and group II. Than similar observation were reported by Awawdeh et al., (2006). The average digestibility of NFE $61.44 \pm 0.79,63.12 \pm 1.68,64.46 \pm 0.72$ percent in I, II, III, group respectively. These data are statistically significant. The higher digestibility coefficient of NFE was recorded in group III. Similar Observation were reported by Ferede et al., (2014). The average digestibility of organic matter $61.29 \pm 1.50$, $62.97 \pm 1.27,63.56 \pm 1.13$ percent in I, II, III, 
group, respectively. These data are statistically significant. Similar observations were reported by Saha et al., (1993).

The showing average of live weight increased were $138.49 \pm 3.46,139.80 \pm 3.55$ and 140.76 $\pm 3.63 \mathrm{~kg}$ in $\mathrm{T} 1, \mathrm{~T} 2$ and groups respectively. The highest live weight was increased in T3 group and lowest was recorded in T1 groups.

The statistical analysis of data showed significant in the increased growth of all the groups. Similar observation in reported by Podhorsky et al., (1984). The showing average length of increased were $125.75 \pm$ $2.96,128.53 \pm 2.92$ and $129.72 \pm 3.70 \mathrm{~cm}$. is T1, T2 and T3 groups, respectively.

The highest average length was increased in T3 group and lowest was found in T1 group statistical analysis of data showed significant. Similar observation in recorded Murty et al., (1982). The showing average heart girth of increased were $150.45 \pm 2.92,151.24+2.59$ and $152.01+2.31 \mathrm{~cm}$ in $\mathrm{T} 1, \mathrm{~T} 2$ and $\mathrm{T} 3$ groups respectively. The highest average length was increased in T3 group and lower was found in $\mathrm{T} 1$ group. The statistical analysis of data showed significant. Similar observations were reported by Rasjid and Barker (1980).

On the basis of above finding, it can be conclude that the concentrate group T3 shown good growth performance in respect to body weight gain, length and heart girth.

It is therefore recommended from the study that the plan of nutrition plays an important role in body growth and fattening performance and poor nutrition resulted is so called poor growth of live weight, length and heart girth. Hence extra concentrate supplement to be added in diet for better performance to growing calves.

\section{References}

Awawdeh, M. S., Titgemeyer, E.C., Schoreder, G.F. and Gand, D.P. (2006)Excess Amino Acid Supply Improves Methionine and Leucine Utilization by Growing Steers. Journal of Animal Science, 84, 1801-1810.

Chauhan, T. R.; Sharma, N. D.; Dahiya, S. S.; Gupta, R.; Arora, U.; Lall, D. (2000). Effect of plane of nutrition on milk yield, composition and nutrient utilization in lactating buffaloes in their early lactation, Buffalo Journal 2000 Vol.16 (2): 215-221 ref.9.

Ferede, Y., Mazengia, H., Bimrew, T., Bitew, A., Nega, M. and Kebede, A. (2014)Improved calf management practices and optimization of more adaptable blood level of crossbred cattle in the study areas would significantly reduce calf mortality and morbidity.

Fluharty, F.L. and Loerch, S.C. (1994) Effects of Energy Density and Protein Source on Diet Digestibility and Performance of Calves after Arrival at the Feedlot. Journal of Animal Science, 72, 16161622.

Madhuri S.B. and Suman C.L (2008) growth performance of progenies of two breed cross in cattle Indian veterinary journal 85: 7 736-738.

Mishra, A.K.; Singh, S.K.; and Maurya, p.; (1994) - Conducted an experiment on crossbred calves to see the different of two different plans of nutrition on growth performance they noted there was no significant difference in intake of calf starter between groups. The total DM intake from birth to 3 months of age and DM intake/Kg. body weight gain did not differ between groups,Indian veterinary journal 84,(3) 651-654.

Murty J., Dailey R., Helmondollar R., Pritchard J. and Osborne P. (1992)- 
Nutritional and Environmental Effects. Journal of Animal Science, 62, 555-560.

Podhorsky, z., Akbulut,o, and Dayioughlu, $\mathrm{H}$ (1994) the effect of late pregnancy feeding on birth weight of calves and the effect on giving extra feed supplement on the calf growth during suckling Hoyancilik Arastirna Deranci 4 (2): 78

Rajagopal, S. and Murty, V.N. (19983). Effect of feeding levels of concentrate nature ad-lib green berseem on nutrient utilization in lactating cows.Kerla $\mathrm{j}$. veterinarysci., 14(2): 115-130

Rajagopal, S. and Murty, V.N.(19983).effect of feeding levels of concentrate nature ad-lib green berseem on nutrient utilization in lactating cows. Kerala $\mathrm{j}$. Veterinary sci., 14 (2):115-130
Rasjid and Barker (1980). Effect of Early Nutritional Experience on the Feeding Behaviour of Adult Female Rats. Veterinarni Medicina, 47, 315-322.

Schloss,. C.F. Abdalla, A.L. and Vitti, DMSS (1911): "The effect of feed supplement on the onset of puberty in Brazilian dairy heifers" Sci. Agricola, 51 (2):374.

Shaha, B; Mehta A.G.; Thakur, S (1993) Effect of supplementing bypass fat on the performance of buffalo calves, n. (indian j. Anim. Nutr., 2007,24 (4): 233236).

Singh Paul, A.K. bhar, L M (2008)-Double and triple cross in cattle Dehradoon farm Indian Journal of Animal Science Science 786 661-665.

\section{How to cite this article:}

Narendra Kumar, Ramjee Gupta, P. K. Upadhyay, Satendra Kumar and Deepak Singh. 2020. Effect of Plane of Nutrition on Growth of Crossbred Calves. Int.J.Curr.Microbiol.App.Sci. 9(11): 1190-1195. doi: https://doi.org/10.20546/ijcmas.2020.911.139 